This is the pre-copy-edited version of the following publication:

Jonathan Godsall, 'Music by Zbigniew Preisner? Fictional composers and compositions in the Kieślowski collaborations', published in Contemporary Film Music: Investigating Cinema Narratives and Composition, edited by Lindsay Coleman and Joakim Tillman, 2017, Palgrave Macmillan. Reproduced with permission of Palgrave Macmillan.

\title{
Music by Zbigniew Preisner? Fictional composers and compositions in the Kieślowski collaborations
}

Jonathan Godsall

Zbigniew Preisner is a composer of many voices. The different facets of his output are evidenced by concerts of his music that took place in London in 1999 and 2007. ${ }^{1}$ The first half of each was devoted to a concert work: in 1999, Requiem for my Friend, Preisner's first such piece, written in honour of the recently deceased director Krzysztof Kieślowski; in 2007, Silence, Night \& Dreams, a large-scale song cycle. The expansion of Preisner's nonfilm output since Requiem - with 2015's Ten Pieces for Orchestra the most recent addition has coincided with a relatively quiet spell in his film-scoring career, with only a handful of assignments having been completed in the last decade, but it is as a film composer that Preisner remains most famous. ${ }^{2}$ In both 1999 and 2007, it was his music for film - and particularly for the films of Kieślowski, with whom he collaborated regularly from 1985's No End to 1994's Three Colours: Red, the director's final film - on which the second halves of the concerts focused.

\footnotetext{
${ }^{1}$ The programme of the 1999 concert can be inferred from reviews. See Jonathan Broxton and James Southall, 'Zbigniew Preisner - In Concert: Requiem for my Friend', Movie Music UK, $<\mathrm{http}: / /$ web.archive.org/web/20081020230549/http://www.moviemusicuk.us/preisint.htm> accessed 13 August 2015, and Tess James, 'Review of Zbigniew Preisner, Requiem for my Friend', Music Theory Online, vol. 5, no. 4 (September 1999), < http://www.mtosmt.org/issues/mto.99.5.4/mto.99.5.4.james.html> accessed 13 August 2015. For the programme of the 2007 concert, see Zbigniew Preisner, Silence, Night \& Dreams, Barbican, 2 December 2007, programme, < http://www.barbican.org.uk/media/events/6112preisnerproglowresforweb.pdf $>$ accessed 13 August 2015.

${ }^{2}$ At the time of writing, some of his non-film compositions - including Ten Pieces - have not been performed outside of the recording studio, but I will nonetheless describe them as 'concert music' below for the sake of consistency and clarity.
} 
Perhaps surprising for anyone not familiar with Preisner's oeuvre, however, would be the opinion of Jonathan Broxton and James Southall, writing of the 1999 concert, that '[t]he highlight of the second half [...] was undoubtedly the performance of Van den Budenmayer's Concerto in E Minor from The Double Life of Véronique [dir. Krzysztof Kieślowski, 1991].'3 The same piece also featured in the later event. How could another composer's work be the highlight of a concert of Preisner's music? The answer, of course, is that Van den Budenmayer is Preisner, or rather, a pseudonym of Preisner's. In Véronique the Concerto is performed in a key scene, and elsewhere in the same film (set in the then-present day) we are informed that Van den Budenmayer was a Dutch composer who lived from 1755 to 1803, but who was 'discovered only very recently'. In reality, though, and along with other pieces 'by' Van den Budenmayer and similarly fictional composers featured in other Kieślowski films, the Concerto was written by Preisner.

Preisner's fictional voices are the concern of this chapter. That the Concerto, a piece effectively written by Preisner not as himself but while pretending to be someone else, was the 'highlight' of that 1999 concert for at least some in the audience is still striking, and illustrates the centrality of such music to his identity as a composer. It is thus an important avenue for exploration in this sense, but also, I will argue, forms an intriguing case study situated within a wider field as yet largely unexplored by musicology.

\section{Fictional music in theory and practice}

The Concerto in E Minor is an example of fictional music, which I define generally as original music, existing within a work of fiction's storyworld, that the work implies has been composed by one or more of its fictional characters. In Véronique the Concerto supposedly written by Van den Budenmayer features in a diegetic concert performance, during which Weronika (Irène Jacob) - the protagonist of the first part of the film, and the soprano soloist for the piece - collapses and dies. Excerpts from it are also performed by other characters in the film, as for instance when Véronique (also Jacob) - Weronika's double, and the focus of the longer second part of the film - leads her school pupils in a rendition of its principal theme.

Given this manner of its representation, the Concerto is more particularly an example of observable-in fictional music. This term I borrow from Paisley Livingston's discussion of

\footnotetext{
${ }^{3}$ Broxton and Southall, 'Zbigniew Preisner'.
} 
'nested art', the broader phenomenon of one artwork being nested within another. Livingston distinguishes between 'artistic structures presented or made observable-in some artistic representation' (what he terms nested artworks) and 'those merely described or evoked, the underlying point being that what nesting makes possible is a direct gauging or appreciation of an artistic structure on display'. ${ }^{4}$ The Concerto is observable-in Véronique because it was actually composed by Preisner and recorded by real musicians, meaning that the film's audience can hear it as music. Other such filmic examples range from the Warsaw Concerto, composed by Richard Addinsell for performance (and supposed composition) by the pianovirtuoso main character of Dangerous Moonlight (dir. Brian Desmond Hurst, 1941), to the songs of the titular band in This Is Spinal Tap (dir. Rob Reiner, 1984). ${ }^{5}$ Examples realized by Preisner and featured prominently within Kieślowski films include other pieces by Van den Budenmayer heard in Decalogue IX (1990), Three Colours: Blue (1993), and Three Colours: Red (1994), music by unnamed composers in Decalogue II (1990) and Véronique, and music by the central composer characters in Three Colours: Blue.

In Blue, Preisner's Song for the Unification of Europe is a piece fictionally begun by the character Patrice de Courcy (Hugues Quester), a celebrated composer, but left to be completed by his wife Julie (Juliette Binoche) and friend Olivier (Benoît Régent) following the deaths of Patrice and his and Julie's daughter. The Song is notable for appearing not only sonically but also in part via notation that is legible to the film's audience. This exemplifies another manner in which fictional music can be observable-in any kind of visual or indeed literary artwork, and also illustrates Livingston's further notions of 'partial nesting' (given that we only see certain pages or staves of the scores) and of the representation of works that are themselves somehow partial or incomplete (given that we see manuscript scores to which changes can be and are made by Julie and Olivier). ${ }^{6}$ In general, though, observable-in fictional music that is more specifically audible-in is the most significant possibility attached to artforms with a sonic component, with non-film examples ranging from the 'Prize Song' of Richard Wagner's Die Meistersinger von Nürnberg (1868) to the country hits of television

\footnotetext{
${ }^{4}$ Paisley Livingston, 'Nested Art', The Journal of Aesthetics and Art Criticism, vol. 61, no. 3 (Summer 2003), 238.

${ }^{5}$ For a discussion of several examples including the Warsaw Concerto, see Ben Winters, Music, Performance, and the Realities of Film: Shared Concert Experiences in Screen Fiction (Abingdon: Routledge, 2014), 47-66. On the songs of Spinal Tap, see John Covach, 'Stylistic Competencies, Musical Humor, and This is Spinal Tap', in Elizabeth West Marvin and Richard Hermann (eds), Concert Music, Rock and Jazz Since 1945: Essays and Analytical Studies (Rochester: University of Rochester Press, 1995), 399-421.

${ }^{6}$ See Livingston, 'Nested Art', 238-240.
} 
show Nashville (2012-). By contrast, novels in particular have encouraged authors to conjure wonderful ekphrastic compositions, as for instance in Thomas Mann's Doctor Faustus (1947) or Anthony Burgess's A Clockwork Orange (1962).

One gets a sense here of how Preisner's fictional music fits into a bigger tradition. It is a uniquely extensive case within that tradition, though, given the network of fictional composers and compositions developed across multiple collaborations with Kieślowski, to be considered further below. Nonetheless, it will still illustrate general aspects of the concept and category of fictional music, particularly of the audible-in type. This phenomenon has so far been underexplored in musicological scholarship, previous studies of particular cases having not addressed the functions and attributes shared by examples of such music beyond a particular text, genre, or medium. ${ }^{7}$

Peter J. Rabinowitz has outlined his own definition of fictional music, as simply 'music that pretends to be a different performance of some other music' ${ }^{8}$ His concern with the phenomenon's presence in concert music and opera can be expanded to include other artforms (music by Preisner, performed by real musicians, pretends to be music by Van den Budenmayer performed by characters in Véronique, for instance), and in any case usefully highlights that fictional music can be nested within other music. Furthermore, an interesting implication of his definition is that fictional music need not be nested at all, though we might say that the music in such cases still appears to generate its own nest (its own fiction, at least), as with Peter Schickele's compositions as P.D.Q. Bach. While I adopt these ideas, though, Rabinowitz also includes in his category quotations of existing, real pieces that are presented within larger musical contexts, as for example in the works of Charles Ives.

Rabinowitz's theories of how we listen to this 'music pretending to be other music' justify his broader remit, and indeed will be drawn upon later in this chapter, but overlook differences between music with its own history and music that is explicitly new, which have implications for both the creators and audiences of texts that include such music. I have appropriated Rabinowitz's term because his definition corresponds to meanings of the adjective 'fictional' less straightforwardly than my own, and is not widely used. ${ }^{9}$

\footnotetext{
${ }^{7}$ These studies, two of which are named in footnote 5 above, of course use different perspectives to aim at different goals. John Covach's essay on This is Spinal Tap explores how listeners' knowledge of certain musical styles affects perception of that film's musical humour, for instance. Covach, 'Stylistic Competencies'.

${ }^{8}$ Peter J. Rabinowitz, 'Fictional Music: Toward a Theory of Listening', in Harry R. Garvin (ed.), Theories of Reading, Looking, and Listening (London: Associated University Presses, 1981), 198.

${ }^{9}$ My definition in fact more closely matches the concept of 'imaginary music' that Rabinowitz coins (but does not fully define or explore) in a discussion of music in Burgess's A Clockwork Orange:
} 
Here, it is nonetheless worth overlooking some differences to consider the telling similarities between examples of fictional pieces such as in Véronique and Blue and cases of the filmic representation of real, pre-existing compositions, all of which fall under Livingston's even broader umbrella of 'nested art'. Take Amadeus (dir. Milos Forman, 1984). Like those Kieślowski films, this has a musical protagonist, albeit a real one: Mozart. And, as in those other films, we witness diegetic musical performances, though the music performed is again now real music that we might say 'plays itself' in the manner of a real person appearing as themselves within a fiction film. ${ }^{10}$ A particularly strong comparison is with Blue, given the composer characters and that the films both depict the compositional process. In Amadeus, this occurs most famously in the deathbed sequence of Mozart (Tom Hulce) dictating the Confutatis of his Requiem to rival Salieri (F. Murray Abraham). The music here is sung by both characters, but also exists in orchestrated form in a seemingly shared internal diegetic space to which the film's audience is given access via a process of internal focalization, meaning that we can hear the piece taking shape as Salieri takes down each part in turn. ${ }^{11}$ In Blue, an equivalent scene features Julie and Olivier working on a completion of Patrice's Song for the Unification of Europe. We hear the piano at which they work but also other instruments not present in the room, this orchestration evolving in real time as Julie suggests changes to the score. Again, we might think of this latter soundtrack component being heard internally by Julie and/or Olivier, though it is present primarily for the audience's benefit.

One difference is that the Requiem escapes the bedroom during the Amadeus sequence: images from that locale are intercut with others of Mozart's wife and son travelling back to Vienna to be with him, but the music (including Mozart's sickly sung dictation of it) continues uninterrupted. This does not occur in the composition scene in Blue. The broader strategy of which the deathbed 'escape' is just one example in Amadeus can be observed

Peter J. Rabinowitz, “'A Bird of Like Rarest Spun Heavenmetal”: Music in A Clockwork Orange', in Stuart Y. McDougal (ed.), Stanley Kubrick's A Clockwork Orange (Cambridge: Cambridge University Press, 2003), 109-130. My objection to this term is largely nomenclatural, for while the sound of ekphrastic music in a novel will have to be imagined by a reader, viewers need not imagine that of a film's audible-in music. 'Fictional music' better reflects the cross-media concept I have outlined.

${ }^{10}$ A difference between Mozart's character and his music in Amadeus is that the character is a fictionalized version of a real, historical figure, whereas the music is the real music, at least compositionally. It is presented in fictional (or fictionalized) performances, however. To paraphrase Rabinowitz, these are performances that pretend to be different performances of the same music.

${ }^{11}$ On the application of the narratological concept of focalization to music in film, see Guido Heldt, Music and Levels of Narration in Film: Steps Across the Border (Bristol: Intellect, 2013), 119-133. 
elsewhere in Kieślowski's film, though, and indeed in Véronique and other of the director's films featuring Preisner's fictional pieces, including some that do not focus on musical characters. Music that appears diegetically can seep out of the narrative into the film's narration, and so function not merely as an element furnishing a believable storyworld but also as 'film score'. In Amadeus and other Mozart biopics that Guido Heldt has studied, this 'links the life and work in a myth-making (or more often myth-reinforcing) feedback loop': 'in some films Mozart becomes Don Giovanni, not just through actions, but through the music; in some films, the Requiem indeed presages his own death, fulfilling the biographical myth, but fulfilling it because of the way the medium works'. ${ }^{12}$ While Kieślowski's films do not interact with historical biography in the same way, their fictional compositions often have similarly symbolic roles to play, and fulfil these by moving fluidly between levels of narration (with their positioning in relation to the diegesis commonly ambiguous) as well as through their own musical attributes.

In Blue, for instance, Nicholas Reyland identifies two themes by Van den Budenmayer, and argues that Julie, the film's protagonist, 'must supplant one [...] with another in order to progress' with her life after the deaths of her husband and daughter. ${ }^{13}$ The first theme is played by an ensemble at their joint funeral, and so is associated with the tragic event that threatens to metaphorically (and perhaps literally) end Julie's life too. The second, though, is a theme that Julie, following the apparent intentions of her husband, weaves into her completion of his Song for the Unification of Europe. This Budenmayer theme, then, represents the closure and control that will allow her to move forward. Though musically similar to the first in many respects (some of which will be considered below), it hints at a major key and so has what Reyland describes as a 'yearning quality', where the first sits unwaveringly in the minor. ${ }^{14}$ It is the second theme that comes to predominate on the soundtrack; Reyland states that '[n]ot to hear this musical exchange is to miss something crucial in Blue's plot.' ${ }^{15}$ And, importantly, neither theme is heard only in diegetic performance. Quite whether they are then always (or ever) truly non-diegetic is a matter for individual interpretation; the film also allows its audience to conceive of cues being internal

\footnotetext{
${ }^{12}$ Guido Heldt, 'Playing Mozart: Biopics and the musical (re)invention of a composer', Music, Sound, and the Moving Image, vol. 3, no. 1 (Spring 2009), 25. Emphasis original.

${ }^{13}$ Nicholas W. Reyland, Zbigniew Preisner's Three Colors Trilogy: Blue, White, Red - A Film Score Guide (Plymouth: Scarecrow Press, 2012), 185. My thanks to Nick for his authoritative book (on which I draw heavily below) and informal discussions with me about this topic.

${ }^{14}$ ibid., 202.

${ }^{15}$ ibid., 185.
} 
diegetic (though never as clearly as in the aforementioned composition scene), or else as somehow supernaturally diegetic (on the idea of which more below). The music can signify different stages in Julie's life in any of these positions, the more significant factor being its detachment from obvious diegetic motivation. At the least, the boundary between narrative and narration is blurred, creating ambiguity emblematic of the film's broader interpretive openness.

In Véronique, too, the Concerto echoes between the lives of Weronika and Véronique not only through its simple diegetic occurrence in both. At the very beginning of the film, for example, we see Weronika in childhood, and hear a foreshadowing of her fate. A presumably non-diegetic recorder plays what is later revealed to be the main theme of the Concerto, but the melody is cut off abruptly before resolution, much as Weronika will later collapse and die during a performance of the same piece. Elsewhere, recurring fragments of the Concerto, both diegetic and not, function much like the repeated visual motifs of reflection and refraction also present throughout the film, contributing to the uncanny atmosphere through which we perceive the doubled lives of the doppelgängers (an atmosphere to which the music's literally unreal status perhaps generally contributes, here and in other Kieślowski films). There is, in fact, very little music in Véronique that does not originate in some respect from the fictional Van den Budenmayer composition. ${ }^{16}$

It is not only within individual films but also across the collaborations of Kieślowski and Preisner that fictional pieces of music can work in these ways. Intertextual connections are a feature of Kieślowski's films more generally: the character of Weronika in Véroniquea singer with a heart condition - is prototyped by a minor character in Decalogue $I X$, for instance, while actor Aleksander Bardini appears in multiple films (bookended by roles as a lawyer in both No End and Three Colors: White [1994]). Musically, the centrepiece of a network that spans from Preisner and Kieślowski's earliest collaboration to their last is Van den Budenmayer, both generally and through the recurrence of specific pieces.

One such recurrence apparently requested by Kieślowski himself is of the Van den Budenmayer 'funeral music' in Blue,${ }^{17}$ which first appeared in No End without being attributed to any particular fictional composer. In the earlier film, the theme is initially heard at moments when Antek (Jerzy Radziwiłłowicz), the recently deceased husband of

\footnotetext{
${ }^{16}$ The notable cues that do not relate to the Concerto are also examples of fictional music: the piece that Weronika sings with her choir at the beginning of the film, and the piano accompaniment that Alexandre uses for his puppet show at Véronique's school. A composer is not named in either case.

${ }^{17}$ See Reyland, Zbigniew Preisner's Three Colors Trilogy, 171.
} 
protagonist Ula (Grażyna Szapołowska), either actually appears as a ghost or is implied to be in Ula's thoughts. These occurrences, in which the melody is orchestrated in different ways, are all most safely interpreted as non-diegetic; no source is actively implied, and significantly neither Ula nor her son Jacek (Krzysztof Krzemiński) are shown to hear the music. Yet near the end of the film, Jacek plays the same melody on their piano (and is shown to write on manuscript paper just prior to doing so, suggesting that he is transcribing or even composing the music) and a shocked Ula bursts into the room, before leaving in tears as Jacek turns back to the piano somewhat indifferently. This event calls the melody's prior status into explicit question, where in Blue and Véronique the ambiguity of music's positioning in relation to the diegesis is not so highlighted.

The No End theme seems to represent Antek not only for the film's audience, but also for its characters; this is the clearest explanation for Ula's anguish. In playing the melody and then appearing to take more interest in it than in his mother's distress, Jacek might be seen to express a connection to his father that he does not share with her. Joseph Kickasola reads a political dimension into this, noting Antek's role as a lawyer defending members of the Solidarity movement and Jacek's apparent nascent interest in that movement, and moreover naming the tune as Jacek Kaczmarski's protest song 'Mury', ${ }^{18}$ an 'unofficial hymn' of Solidarity. ${ }^{19}$ Importantly, however, its melody is shaped differently to that of 'Mury' (which was written to the tune of Lluis Llach's Catalan protest song 'L'Estaca'), though it is similar in its phrasing and range and so was perhaps designed to evoke Kaczmarski's song. Indeed, Reyland spots a resemblance to the Polish hymn 'Holy God' that he confirmed as deliberate in his own interviews with Preisner. ${ }^{20}$ Again, though, the melody is similar but clearly not the same; the theme in No End is original and thus fictional music (Figs. 5.1, 5.2, and 5.3).

Fig. 5.1: No End melody, Jacek's piano version. Music by Zbigniew Preisner. (C) Copyright 1985 Amplitude Publishing. Used by Permission

[Fig. 5.1 here]

\footnotetext{
${ }^{18}$ Joseph Kickasola, The Films of Kryzysztof Kieślowski: The Liminal Image (New York: Continuum, 2004), 156-157.

${ }^{19}$ José M. Faraldo, 'Spain: The Common Experience of Transition and a Military Coup', in Idesbald Goddeeris (ed.), Solidarity with Solidarity: Western European Trade Unions and the Polish Crisis, 1980-1982 (Plymouth: Lexington Books, 2010), 59.

${ }^{20}$ Reyland, Zbigniew Preisner's Three Colors Trilogy, 15.
} 
Fig. 5.2: 'L'Estaca' (first two phrases, transposed from A minor into G minor for ease of comparison). (C) Copyright 1968 by Lluis Llach Grande; SEEMSA, Alcalá 70, 28009 Madrid (Spain). Used by permission

[Fig. 5.2 here]

Fig. 5.3: Refrain from 'Holy God' ('Święty Boże', traditional Polish church song)

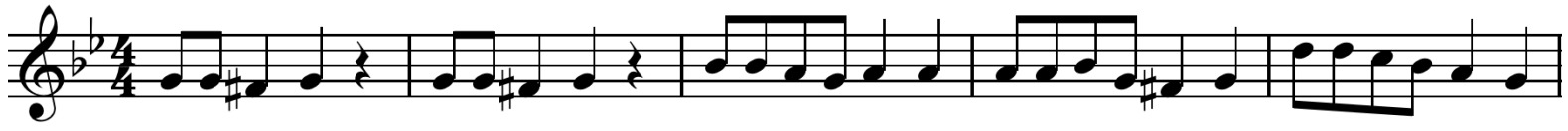

Given the appearance of Antek's ghost at various points in the film, a supernatural interpretation of the music's recurrence and eventual diegetic utterance would not be inappropriate (though this is not to say that it would be an inappropriate way of understanding the ambiguous status of music in Blue and Véronique; the supernatural is emphasized in No End, but might also explain Véronique's doublings, for instance). Has the tune also been a ghost, literally haunting Ula and Jacek? (Does Jacek even play it? After all, the camera cuts away to shots of Ula in another room at the moment we hear the piano.) Reyland suggests that 'the music's crossing between afterlife and life, nondiegetic score and diegesis, anticipates the border crossing Ula will undertake' upon her eventual suicide, implying a ghostly reading on his part. ${ }^{21}$ The connection to either or both 'Mury' and 'Holy God' hints at a straightforward reason for the association with Antek the melody seemingly holds for Ula and Jacek, though, namely that they associated it with him at a time prior to the film's narrative. Ula might even have been hearing it internally at some or all of its earlier moments of occurrence during that narrative (in which case 'haunting' could still be an appropriate description of its relationship to her, if in a more mundane sense). While its evocation of a protest song suggests an association with Antek's life, the theme's resemblance to a hymn (and its rather funereal musical character) points instead to Antek's death, and specifically his funeral. This second connection is then, of course, supported by the same music's later appearance as Blue's first Van den Budenmayer theme, played at the funeral of Julie's husband and daughter.

That this apparent confirmation occurs only in another film eight years later is precisely the point: No End might imply this reading, but leaves its audience to fill in the

${ }^{21}$ ibid., 98. 
gaps. Whether Kieślowski and Preisner intended the theme's use as funeral music in Blue to reflect back onto No End in this way is unclear; in any case, it does. Its repetition also more generally connects the mourning processes of the two widows, emphasizing the importance of Julie supplanting this theme with the other, given that Ula's inability (or unwillingness) to escape it leads to her suicide. Such is the multidimensional manner in which Preisner's fictional pieces can function both within and between Kieślowski’s films.

\section{Composing fiction}

The nature of the regular and trusting collaboration between Kieślowski and Preisner was key to the construction of the unique universe of fictional music that envelops their films, both in the sense of allowing that universe to develop over the course of multiple projects, and in that of pushing the music to the foreground in many of them. Preisner has said that 'the music in [Kieślowski's] films was considered as part of the initial concept', ${ }^{22}$ and that

[f]or Véronique I recorded about 80 per cent of the music before the film was shot and for Blue I recorded almost all the music before the shooting. The music was already prepared for in the scripts; Krzysztof and his co-screenwriter generally made very precise indications in their scripts with instructions, such as 'Here the music will play for 45 seconds or one minute ten seconds. ${ }^{23}$

Kieślowski himself remarked that, '[i]n a way, [Blue] was shot as an illustration of the music'. ${ }^{24}$

What are the processes by which a real person goes about writing music 'in character' as a fictional one, though? This is an intriguing question to be asked in relation to any fictional music (even if it is only described and not actually composed); the peculiarity of this creative process provides much of the justification for defining and exploring this category in the way I suggest. That there is a whole genre of such music within the Preisner-Kieślowski collaborations - including multiple pieces 'by' the same fictional composer, and similar pieces 'by' multiple different fictional composers, all of which can be compared - makes that genre in many respects the ideal fictional music case study.

\footnotetext{
${ }^{22}$ In Mark Russell and James Young, Film Music: Screencraft (Woburn: Focal Press, 2000), 167.

${ }^{23}$ In Geoffrey Macnab and Chris Darke, 'Working with Kieślowski', Sight and Sound, vol. 6, no. 5 (May 1996), 20.

${ }^{24}$ Quoted in ibid., 22.
} 
The creative process here must be mostly inferred through examination of Preisner's pieces as they exist in their final forms, though. Preisner has said little about how he composes 'in character' in previous interviews, and remarks in our interview only that 'I try to be that composer. I think about what he wants to say, what music language and style.' A tendency not to intellectualize his own process is present in regard to other aspects of his work and indeed in other interviews too, and so does not relate specifically to the subject of his fictional alter egos. Nonetheless, that Preisner acknowledges the notion of his playing a role in these cases, allowing fictional musical voices to speak through his own, validates a useful way of conceptualizing this process from a scholarly perspective.

Imitation is probably the most obvious method of writing in another voice, as evidenced by the abundance of examples of pastiche and emulation in cases of fictional music. The Beatles-alike songs of make-believe band The Rutles, as already usefully discussed by John Covach, ${ }^{25}$ present only the most obvious examples of pieces that might be fruitfully studied as instances of applied musical analysis and criticism (obvious because their targets and lovingly satirical intent are so apparent). In the case of alleged late-eighteenthcentury Dutch composer Van den Budenmayer, Preisner at least eschewed possibilities for imitation of music by historically or culturally appropriate figures, describing his alter ego's style as 'close to Neo-Romanticism, with its mixture of Classical Romanticism and the compositional techniques of contemporary music'. ${ }^{26}$ While the evident (and at least partly intentional) relation of the Blue/No End funeral music to Polish melodies discussed above also does not point to the Netherlands, though, it does point to Preisner's imitative abilities. ${ }^{27}$ Citing his own interviews with Preisner, Reyland also suggests then-recent compositions of Krzysztof Penderecki's late neo-Romantic style as a model for the Song of Blue's present-day composers, and intriguingly points out that Preisner 'vehemently dislikes' this style, an issue to which I will return shortly below. ${ }^{28}$

External models aside, Reyland hears a common 'Budenmayeran quality' in the two themes in Blue, noting amongst other attributes that they are both in minor keys

\footnotetext{
${ }^{25}$ John Covach, 'The Rutles and the Use of Specific Models in Musical Satire', Indiana Theory Review, vol. 11 (1991), 119-144.

${ }^{26}$ In Macnab and Darke, 'Working with Kieślowski', 20.

${ }^{27}$ The most famous example of imitation in his scoring is a non-fictional cue in White. Preisner explains: "When, finally, the hero arrives back in Warsaw and is thrown on to a garbage dump he surveys his surroundings and exclaims, "Home at last". The music becomes very like Chopin, a Polish cultural icon - it was ironic. At that time Poland was one huge garbage dump.' In Russell and Young, Screencraft, 168.

${ }^{28}$ Reyland, Zbigniew Preisner's Three Colors Trilogy, 40.
} 
(notwithstanding the second theme's suggestion of its relative major, mentioned above), have similar slow tempi, and share 'aspects of phrasing and rhythm'; dotted figures are the most obvious of the latter (Figs. 5.4 and 5.5). ${ }^{29}$ The main theme of the Concerto in Véronique, too, shares all of these attributes, as well as the combination of stepwise and chordal melodic movement present in both melodies above (Fig. 5.6).$^{30}$ The cadential melody of the song that first appears in Decalogue $I X$, and later recurs in Red, also exhibits these melodic characteristics, further pivoting around the second degree of the scale in a manner common to Van den Budenmayer's other conclusions (Fig. 5.7). This all suggests that Preisner follows certain compositional 'rules' when writing in character.

Fig. 5.4: Van den Budenmayer funeral music in Blue. Music by Zbigniew Preisner. (C) Copyright 1994 MK2 SA, Chester Music Limited. All Rights Reserved. International Copyright Secured. Used by Permission of Chester Music Limited

[Fig 5.4 here]

Fig. 5.5: Second Van den Budenmayer theme in Blue (as initially heard in Julie's version of the Song). Music by Zbigniew Preisner. (C) Copyright 1994 MK2 SA, Chester Music Limited. All Rights Reserved. International Copyright Secured. Used by Permission of Chester Music Limited [Fig. 5.5 here]

Fig. 5.6: Main theme, Van den Budenmayer Concerto in E Minor from Véronique. Music by Zbigniew Preisner. C Copyright 1991 Delabel Editions SARL/New Music BV. Used by Permission of Sony/ATV Music Publishing (Germany) GmbH

[Fig. 5.6 here]

Fig. 5.7: Cadential melody, Van den Budenmayer song from Decalogue IX. Music by Zbigniew Preisner. (C) Copyright 1989 Amplitude Publishing. Used by Permission

[Fig. 5.7 here]

${ }^{29}$ ibid., 202.

${ }^{30}$ The similarities are such that, argues Reyland, '[i]t is even just about possible to imagine that the [second Van den Budenmayer theme in Blue] is a reminiscence (misremembered by Patrice?) of the [...] Concerto heard in Véronique.' ibid., $415 \mathrm{n} 129$. 
The living composers in Blue - Julie and Olivier - share the "conservative diatonic palette' that Reyland identifies as underpinning Van den Budenmayer's work, ${ }^{31}$ and also have their own recognisable traits - their own generative 'rules', perhaps - in being differentiated through stereotypically feminine and masculine musical voices. In the composition scene mentioned earlier, for example, Julie feminizes an orchestration previously completed by Olivier, removing percussion and trumpet from the first melody, and settling on a solo recorder instead of a piano for the second. ${ }^{32}$ Both of these melodies in fact appear to be inventions of Olivier's and not Patrice's, or at least are notable for not appearing in Julie's own eventual completion of the Song as heard in the film's celebrated final montage. ${ }^{33}$ The rapid rising gesture that opens the first, with the strong pitches of a minor triad outlined over a stable bass, might be interpreted as particularly masculine (Fig. 5.8).

Fig. 5.8: Olivier's theme from Blue. Music by Zbigniew Preisner. (C) Copyright 1994 MK2 SA, Chester Music Limited. All Rights Reserved. International Copyright Secured. Used by Permission of Chester Music Limited

[Fig. 5.8 here]

This theme is first heard around ten minutes prior to the composition scene: Olivier plays it on his piano for Julie, albeit lightly and with an arpeggiated accompaniment in the left hand. Olivier is in love with Julie, and the manner in which he intently focuses on her as he plays suggests a desire for her approval not only musically; the masculine nature of the theme promotes a reading of the scene as an awkward attempt at seduction, in response to which Julie appears unmoved. A few minutes later, however, and indeed after the final utterance of the funeral music connected with Julie's previous life (amongst other significant events), the theme returns without diegetic motivation, still for solo piano but now in the more forceful guise shown above. Here it seems to cue Julie's return to Olivier's apartment to

\footnotetext{
${ }^{31}$ ibid., 75

${ }^{32}$ Olivier later declines Julie's assistance, asserting that 'this music can be mine. A little heavy and awkward, but mine'.

${ }^{33}$ Reyland notes practical and other reasons for this, pointing out that the theme was present in Preisner's manuscript score for Julie's version. Reyland, Zbigniew Preisner's Three Colors Trilogy, 422-423n128. The final form of Julie's version in the film nonetheless suggests this authorial attribution, though the question of who authors much of Blue's fictional music is a murky one more generally, as Reyland also explores. See ibid., 130-132.
} 
work on the music with him, and so also their eventual sexual relationship, in which Olivier is portrayed as dominant by the final montage's image of Julie pressed between him and a fish tank. ${ }^{34}$

That the fictional music in Kieślowski's films is often required to play such symbolic parts, as also seen with other examples discussed above, would have made Preisner's task in composing it all the more difficult. This music must do multiple things at once, and its general success in doing so forms the basis for Reyland's defence of the Song in particular against those who criticize that piece for not sounding like the great twentieth-century concert music Blue's plot arguably requires it to be. ${ }^{35}$ Indeed (and recalling Preisner's own opinion of the neo-Romantic Penderecki repertoire on which he might have modelled the piece), Reyland wonders whether the Song's 'very artifice might not also be a carrier of meaning', asking, '[t]o what degree do Preisner's neo-romantic avatars satirize a tradition he disdains?' ${ }^{36}$

\section{The fictional and the real}

Preisner himself calls Blue's Song 'pompous'. ${ }^{37}$ Its fictional status as an anthem for European unification places it in what Kieślowski described as a context of 'elevated tones and exceptionally weighty words - to put it positively - or bombast - to put it negatively', ${ }^{38}$ and suggests that the composer commissioned to write it - Patrice - is more conservative populist than high-art progressive (as does the media coverage of his death shown in the film).$^{39}$ To hear it as at once unadventurous and pretentious is therefore not only possible, but seemingly authorially sanctioned.

\footnotetext{
${ }^{34}$ As Reyland puts it, 'a man is back on top in Julie's life and she is shown here to be not just subjugated but suffocating in her new position'. ibid., 235 .

${ }^{35} \mathrm{He}$ argues that ' $[\mathrm{t}]$ he most tedious subtext to criticism of the [Song] is a damning of the music as if it were being offered as a piece of actual Western art music, as opposed to a fictionalized representation thereof performing unique symbolic functions in the context of a narrative film.' ibid., 125 .

${ }^{36}$ ibid., 75, 40.

${ }^{37}$ In ibid., 126.

${ }^{38}$ In Paul Coates, "“The Inner Life Is the Only Thing that Interests Me": a conversation with Krzysztof Kieślowski', in Coates (ed.) Lucid Dreams: The Films of Krzysztof Kieślowski (Trowbridge: Flicks Books, 1999), 174. Quoted in Reyland, Zbigniew Preisner's Three Colors Trilogy, 125.

${ }^{39}$ Geoff Andrew, The Three Colours Trilogy (London: British Film Institute, 1998), 88n10. Quoted in Reyland, Zbigniew Preisner's Three Colors Trilogy, 125.
} 
Why, then, did the piece appear as the finale to both concerts of Preisner's music mentioned at the start of this chapter, and indeed on the 1995 'best of' compilation album Preisner's Music (itself a recording of a live event), in that latter case with no reference in the track listing or liner notes to any fictional composer? ${ }^{40}$ The apparent care that Preisner takes over releasing his film music for extra-filmic consumption - summarized by his statement in the interview here that 'some music can be heard without film, some not' - might be read as incompatible with the 'pompous' Song's straightforward presentation for such consumption, given that some listeners inevitably will not have seen Blue. Then again, music composed as (fictional) concert music is in one sense a logical choice for presentation in that manner. And the success of the Song outside of its filmic context could be taken as an example of the gap that inevitably exists between intention and reception, and moreover as calling into question the validity of suggestions that the piece is not 'good' real-world concert music, in a way at least.

As for the Penderecki connection, the accessible style and harmonic soundworld that the older composer's late neo-Romantic works share with Preisner's fictional compositions are complemented by more specific similarities. The orchestra, choir, and soprano soloist scoring of Blue's Song, for example, in fact most obviously prefigures that of Penderecki's Symphony No. 7 ('Seven Gates of Jerusalem’), a 1996 work for orchestra, choir, vocal soloists, and narrator, and Credo, from 1998 and for orchestra, choir, children's choir, and vocal soloists. The more intriguing pre-echo, though, particularly in light of his apparent distaste for this style, is of some of Preisner's own concert music, which we might reasonably understand to represent his own voice most directly.

Given the tendency of fictional pieces in Kieślowski's films to escape the diegesis, it is often hard (and, arguably, pointless) to distinguish between those pieces and Preisner's 'own' scoring for the purposes of analysis. This blurred line between 'real' and 'fictional' aspects of the composer's output also exists on a larger scale. Preisner acknowledges in our interview that his and Van den Budenmayer's styles are 'similar', for instance, which is to be expected given that Preisner's fictional voices emanate from the same background of (a lack of formal) training and influence as his own. ${ }^{41}$ Perhaps more interesting is the possibility that composing 'in character' has provided opportunities for the development of his own voice.

\footnotetext{
${ }^{40}$ Zbigniew Preisner, Preisner's Music (Virgin 72438407992 5, 1995). CD.

${ }^{41}$ See Reyland, Zbigniew Preisner's Three Colors Trilogy, 20-21.
} 
Requiem for my Friend, Preisner's first concert work, was, after all, composed only after the collaborations with Kieślowski that gave rise to those opportunities. It features stylistic traits that illustrate the blurred general divide between real and fictional, including writing for solo recorder (and specifically the recorder of regular collaborator Jacek Ostaszewski) that echoes the prominent use of that instrument not only in fictional contexts (as in the Blue composition scene mentioned above) but also, for example, on the score to the fictional-music-less Decalogue I. More particularly, though, the Requiem's solo soprano part, for one, was written specifically for (and has since been performed and recorded by) the voice of Elżbieta Towarnicka, most familiar from the solo roles similarly taken for Blue's Song, Véronique's Concerto, and the Van den Budenmayer song heard in Decalogue IX and Red. And its second half - titled 'Life', and scored for orchestra, choir, and other vocal and instrumental soloists alongside Towarnicka and Ostaszewski - notably has more in common with the 'monumental' sound of pieces by Van den Budenmayer and the composers in Blue than it does with the restrained, sparse cues that otherwise characterize Preisner's scores for Kieślowski and others.

Of course, the nature of a film composer's regular scoring work might force them to write music in a 'voice' that does not come naturally, which could itself act in the development of their own 'sound'. Fictional music undoubtedly presents particular opportunities and challenges in this regard, though. A piece of fictional concert music will inherently have more in common with a real concert piece than a film score cue in many respects. But while a developmental reading is therefore tempting in Preisner's case, it might equally be true that consistency between his real and fictional work owes to nothing more than a relatively unchanged, pre-existing response to the demands of concert composition, for which the Kieślowski collaborations simply provided the first opportunities.

Either way, the resemblance to fictional pieces of the Requiem in particular remains, and if anything is highlighted by Preisner's freer exploration of other aspects of his voice in later concert works. Pop and jazz influences are audible in the Requiem's solo saxophone writing, for instance, but more fully characterize many of the rhythms, harmonies, and simple lyrical melodies of Ten Easy Pieces for Piano (1999). And a 'New Age' aesthetic is apparent in subsequent large-scale works such as Silence, Night and Dreams (for orchestra, choir, and instrumental and vocal soloists). While this broader fluidity of Preisner's voice could suggest that his fictional compositions have played a less important part in the evolution of his style than proposed above, in order to account for that fluidity we might nonetheless forward the idea of 'playing different characters' as one way of understanding his approach (and perhaps 
that of other composers with similarly varied outputs) to writing individual works of any kind.

What about the questions raised by the potentially critical pomposity of Blue's Song, though? Similarities of the Requiem to that piece are not only broad; the later work's 'Kai Kairos' movement features what appears to be a quotation of Olivier's masculine-flirtation theme (Fig. 5.8 above), arguably the most pompous music in Blue (Fig. 5.9). It is unclear whether this was a deliberate quotation, and if so what the reasoning was behind it. In any case, the musical similarity encourages us to interpret the movement via Blue, and to search for potential authorial intent in so doing. The movement's lyrics are adapted from Ecclesiastes 3:1-8 ('To every thing there is a season, and a time to every purpose under the heaven; $[\ldots]$ '), with the theme heard directly after an opposition of time 'to mourn' and time 'to dance'. Are we to recall the role of Olivier (and this melody) in moving Julie from a state of mourning to one of dancing (figuratively), one enactment of the text's meaning? Maybe so, but then what is to stop us from understanding this music as satire in the same way that the Song might be understood? Are we meant to not take the Requiem (or its second half, at least) seriously? Given its dedication to Kieślowski, this is surely not the case. Preisner refers to the work's final 'Prayer' movement being 'very personal':

I am asking for the strength to go on living in this sad situation. In my life, there were only very few people I wanted to spend time with. One of them was Krzysztof. This prayer is also a request, that such friendship could be found once more. ${ }^{42}$

Fig. 5.9: Requiem for my Friend, 'Kai Kairos', bars 84-87. Arranged by Zbigniew Preisner. (C) Copyright 1996 Chester Music Limited. All Rights Reserved. International Copyright Secured. Used by Permission of Chester Music Limited

[Fig. 5.9 here]

The lack of clarity here owes broadly to a blurring of the real and the fictional. The line between these states is being crossed in much of what has been discussed above. Most notable is that fictional music audible-in a work of fiction inherently straddles that line: such music is fictional and yet also inarguably real, because we can hear it. The relationship of a

${ }^{42}$ In James, 'Review of Zbigniew Preisner'. 
fictional piece - a fictional utterance - to reality is thus very different to that of fictional entities such as characters or physical objects. In this specific case, there are intriguing convolutions. The music of Blue's composition scene is, as Reyland notes, 'music that might be, rather than music that was or yet is', for example. ${ }^{43}$ And yet, through realizing music that does not and might never formally exist (as a published, performed, publicly available composition) in the fictional storyworld, Preisner creates music that does and always will exist in that way for us. Conversely, the films also imply the existence of music that the fictional audience has and will hear - earlier works by Blue's Patrice, for instance - but that we cannot.

The presence and presentation of Preisner's fictional music in concert, on record, as published sheet music and elsewhere in real life takes this further, with fictional pieces appearing alongside and even within real ones. While the appearance of Olivier's theme in Preisner's Requiem provides an apparent example of self-quotation, note also the sampling of Véronique's Concerto in German rapper Spax's 'Psycho' (2003) and Philadelphian hip-hop duo OuterSpace's 'Written in Blood' (2011) (the latter containing the rather appropriate-toVéronique refrain lyric 'Live life after death'), and of the Blue/No End funeral music in 'La Quête' (1998) by Québécois hip-hop group La Constellation. Van den Budenmayer's music here escapes even further into reality (in cases of life-art imitating art-art, given Julie's quotation of another Van den Budenmayer melody in her completion of the Song). ${ }^{44}$

The real-world existence of this music can, moreover, have implications for interpretation of the film(s) from which it originates. As a simple but significant example, while I have suggested above that the re-appearance of music from No End in Blue clarifies our understanding of its meaning for the earlier film's characters, a not dissimilar process in fact clarifies its identity in both films, for in neither is there any mention of it having been composed by Van den Budenmayer. Reyland points to Blue's screenplay and cue sheet as confirming its alleged origin, ${ }^{45}$ but more relevant for the majority of audience members would be Blue's soundtrack release, which labels it similarly. ${ }^{46}$

\footnotetext{
${ }^{43}$ Reyland, Zbigniew Preisner's Three Colors Trilogy, 226. Emphasis original.

${ }^{44}$ Consideration of the sampled music's functions and effects in those songs is beyond the remit of this chapter. The sampling of Addinsell's Warsaw Concerto in DMX's 'What's My Name' bears comparison in terms of the sample's fictional status, and is discussed in Michael Long, Beautiful Monsters: Imagining the Classic in Musical Media (London: University of California Press, 2008), 33-41.

${ }^{45}$ Reyland, Zbigniew Preisner's Three Colors Trilogy, 184.

${ }^{46}$ Zbigniew Preisner, Trois Couleurs: Bleu - Bande Originale du Film (Virgin 724383902729 , 1993). CD.
} 
More generally, and particularly given that the para- and extra-textual forms of these pieces are often somehow different than those heard in the films (Blue's soundtrack release features organ versions of both Van den Budenmayer themes, for instance, which are not heard in the film and so seem to offer a glimpse of a bigger oeuvre), these other existences of Preisner's fictional compositions do not just extend the 'experiences' of Kieślowski's films beyond the end credits (in the manner of other cases of film music's real-world reception in, say, concert-hall performances). More specifically, they extend their fictions into the real world. In the terms of Kendall Walton's conception of fiction, they are 'props' that allow and, if encountered, prompt the continuation of the games of make-believe that audiences are initially encouraged to play by Kieślowski's films. Those films set the 'principles of generation' that mandate our imagining that the pieces were composed and interacted with by fictional characters. When the pieces are later heard elsewhere they can thus, like the tree stumps imagined to be bears as per the rules of a child's game of make-believe, renew our investment in the fictional worlds that originally surrounded them. ${ }^{47}$

Rabinowitz forwards a similar idea of the audience playing a role, applicable here despite his wider definition of fictional music. He states that, in order to fully comprehend and appreciate such music, 'we must listen to [it] simultaneously as what it is and what it appears to be', and suggests that doing so might involve our pretending to hear that music in a different time and/or place - those of its fictional reception, rather than those in which we actually hear it - and moreover in a different evaluative light. ${ }^{48}$ The latter point sets up another riposte to those critics who argue that Blue's Song is of inadequate quality, namely that those critics are not 'playing the game', though they are of course entitled not to do so. ${ }^{49}$ Given the potential for Preisner's fictional pieces to be encountered in real-world contexts that might not highlight their fictional status at all, and/or by audiences not familiar with Kieślowski's films, differences of opinion might also occur for more innocent reasons; this is

\footnotetext{
${ }^{47}$ See Kendall Walton, Mimesis as Make-Believe: On the Foundations of the Representational Arts (Cambridge: Harvard University Press, 1990). The potential for solely non-diegetic cues (and 'real' diegetic music) to prompt such make-believe when heard outside of the cinema would be an interesting topic for future thought. If one agrees with Ben Winters's suggestion that a film's characters can experience the music conventionally thought of as non-diegetic that surrounds them, the specificity of fictional music's ability to act in this way disappears entirely, though the distinctions between it and other kinds of music in this regard might not be concrete in any case. See Winters, Music, Performance, and the Realities of Film, 172-198.

${ }^{48}$ Rabinowitz, 'Fictional Music', 199-203.

${ }^{49}$ Walton notes that, while art appreciation will generally involve playing games of make-believe, art criticism will often not, for it might instead attend solely to questions of how the art functions. Walton, Mimesis as Make-Believe, 53.
} 
music that leads a double life, like Véronique's doppelgängers. ${ }^{50}$ Rabinowitz asserts that it is often the context in which such music is presented that cues us to listen in the manner he suggests, and this is probably particularly true with fictional pieces like Preisner's, which are not obviously silly or satirical in the manner of, say, the songs of Spinal Tap. ${ }^{51}$ When Preisner's compositions fly their fictional nests, they can easily defy Rabinowitz's ideal mode of interpretation. Much as the filmic roles of these pieces are characterized by ambiguity and by the music's moving freely in and around narrative spaces, then, so in the real world this fictional music, precisely because of such music's peculiar relationship with reality, displays a fluidity of identity and of the potential interactions that it directly invites. In this sense, it is arguably the music most representative of its multi-voiced composer.

${ }^{50}$ Preisner has in the past also claimed Van den Budenmayer to be a real composer, as for instance in Mikael Carlsson and Peter Holm, 'The Double Life of Zbigniew Preisner', Music from the Movies, May 1997, 40-41.

${ }^{51}$ Rabinowitz, 'Fictional Music', 207-208n12. 


\section{References}

Broxton, Jonathan and James Southall, 'Zbigniew Preisner - In Concert: Requiem for my Friend', Movie Music UK,

<http://web.archive.org/web/20081020230549/http://www.moviemusicuk.us/preisint.htm> accessed 13 August 2015.

Carlsson, Mikael and Peter Holm, 'The Double Life of Zbigniew Preisner', Music from the Movies, May 1997, 38-42.

Covach, John, 'The Rutles and the Use of Specific Models in Musical Satire', Indiana Theory Review, vol. 11 (1991), 119-144.

Covach, John, 'Stylistic Competencies, Musical Humor, and This is Spinal Tap', in Elizabeth West Marvin and Richard Hermann (eds), Concert Music, Rock and Jazz Since 1945: Essays and Analytical Studies (Rochester: University of Rochester Press, 1995), 399-421.

Faraldo, José M., 'Spain: The Common Experience of Transition and a Military Coup', in Idesbald Goddeeris (ed.), Solidarity with Solidarity: Western European Trade Unions and the Polish Crisis, 1980-1982 (Plymouth: Lexington Books, 2010), 51-73.

Heldt, Guido, Music and Levels of Narration in Film: Steps Across the Border (Bristol: Intellect, 2013).

Heldt, Guido, 'Playing Mozart: Biopics and the musical (re)invention of a composer', Music, Sound, and the Moving Image, vol. 3, no. 1 (Spring 2009), 21-46.

James, Tess, 'Review of Zbigniew Preisner, Requiem for my Friend', Music Theory Online, vol. 5, no. 4 (September 1999), <

http://www.mtosmt.org/issues/mto.99.5.4/mto.99.5.4.james.html> accessed 13 August 2015.

Kickasola, Joseph, The Films of Kryzysztof Kieślowski: The Liminal Image (New York: Continuum, 2004). 
Livingston, Paisley, 'Nested Art', The Journal of Aesthetics and Art Criticism, vol. 61, no. 3 (Summer 2003), 233-245.

Long, Michael, Beautiful Monsters: Imagining the Classic in Musical Media (London: University of California Press, 2008).

Macnab, Geoffrey and Chris Darke, 'Working with Kieślowski', Sight and Sound, vol. 6, no. 5 (May 1996), 16-22.

Preisner, Zbigniew, Preisner's Music (Virgin 72438407992 5, 1995). CD.

Preisner, Zbigniew, Silence, Night \& Dreams, Barbican, 2 December 2007, programme, < http://www.barbican.org.uk/media/events/6112preisnerproglowresforweb.pdf $>$ accessed 13 August 2015.

Preisner, Zbigniew, Trois Couleurs: Bleu - Bande Originale du Film (Virgin 72438390272 9, 1993). CD.

Rabinowitz, Peter J., “"A Bird of Like Rarest Spun Heavenmetal”: Music in A Clockwork Orange', in Stuart Y. McDougal (ed.), Stanley Kubrick's A Clockwork Orange (Cambridge: Cambridge University Press, 2003), 109-130.

Rabinowitz, Peter J., 'Fictional Music: Toward a Theory of Listening', in Harry R. Garvin (ed.), Theories of Reading, Looking, and Listening (London: Associated University Presses, 1981), 193-208.

Reyland, Nicholas W., Zbigniew Preisner's Three Colors Trilogy: Blue, White, Red - A Film Score Guide (Plymouth: Scarecrow Press, 2012).

Russell, Mark and James Young, Film Music: Screencraft (Woburn: Focal Press, 2000)

Walton, Kendall, Mimesis as Make-Believe: On the Foundations of the Representational Arts (Cambridge: Harvard University Press, 1990). 
Winters, Ben, Music, Performance, and the Realities of Film: Shared Concert Experiences in Screen Fiction (Abingdon: Routledge, 2014). 